\section{Ten Years of Progress in the Treatment of Non-Hodgkin's Lymphoma}

\author{
Julie M. Vose, MD, MBA
}

Over the past decade considerable progress has been made in understanding the different types of non-Hodgkin's lymphoma (NHL), including the genetic abnormalities specific to these lymphomas and the optimal clinical management. The initial NCCN Clinical Practice Guidelines in Oncology (NCCN Guidelines) for NHL in 2001-2002 were very basic and included broad recommendations regarding the diagnosis and therapy for 8 different histologic types of NHL. The guidelines were 48 pages in length and represented a prototype that has been refined over the past decade. Major additions and modifications have included new information on molecular data, prognostic factor indices, testing used for response to therapy, new therapies, response criteria, and survivorship issues.

Some of the changes over the past decade are outlined in Table 1. Examples of molecular data found to be helpful for prognosis or deciding therapy include those from testing for the $17 \mathrm{p}$ abnormality in chronic lymphocytic leukemia/small lymphocytic lymphoma or the $\mathrm{t}(11 ; 18)$ in gastric marginal zone lymphoma. Various prognostic factor indices have been developed over this time, including the Follicular Lymphoma International Prognostic Index (FLIPI) and the Mantle Cell Prognostic Factor Index (MIPI), which were added to the guidelines. A decade ago, gallium scans and lymphangiograms were still in the guidelines and have now been replaced by PET scans. With the widespread use of PET scans, the response criteria was modified to include the use of PET scans in patients with appropriate histologic subtypes, such as diffuse large B-cell lymphoma (DLBCL). Multiple new drugs and combinations have been added to the guidelines based on the scientific evidence available. This included the use of rituximab for an increasing number of histologic types of B-cell lymphomas, starting with just follicular lymphoma, and then in combination with chemotherapy for DLBCL (2004) and mantle cell lymphoma (2005). New agents added to the guidelines during the past decade include bortezomib, bendamustine, lenalidomide, and, more recently, agents specific for some subtypes of NHL, such as romidepsin or pralatrexate for peripheral T-cell lymphoma. In many cases, clinical trials are listed as the first option for the treatment of some subtypes of NHL when standard therapy options produce results that are not optimal. As we have become more successful in treating some types of lymphoma, long-term survivors have faced several issues, such as fertility, that have also been more recently addressed in the guidelines.

Additional guidelines have been added over the past decade to assist in the treatment for patients with rare types of NHL, including HIV-associated NHL, mycosis fungoides, peripheral T-cell lymphoma, adult T-cell leukemia/lymphoma, posttransplant lymphoproliferative disorders, and Waldenström's macroglobulinemia. Many of the different histologies have guidelines and recommendations for therapies that are very specific based on the individual subtype of lymphoma and the affected patient population.

When either new antineoplastic agents are approved by the FDA or significant clinical information becomes available about a new drug or combination therapy, the NCCN Guidelines for NHL have been quickly updated to incorporate this information. The future of clinical care for patients with lymphoma will be highly invested in the identification of genetic abnormalities and pathways that can be targeted by new agents. Rather than being one-size-fits-all, personalized therapies

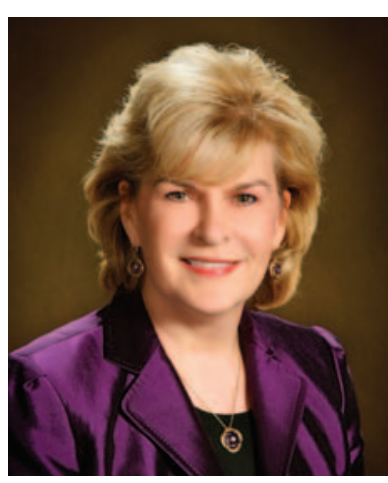

Julie M. Vose, MD, MBA

Julie M. Vose, MD, MBA, is the Neumann M. and Mildred E. Harris Professor and Chief in the Division of Oncology/ Hematology at the University of Nebraska Medical Center in Omaha, Nebraska. Dr. Vose received her medical degree, completed her residency in Internal Medicine, served as Chief Resident, and completed a Fellowship in Hematology/ Oncology at the University of Nebraska Medical Center. She also completed a Masters in Business Administration in Health Administration from the University of Colorado Business School in 2011.

Dr. Vose has focused her career on translational research for improvement in the therapy of non-Hodgkin's lymphoma (NHL) and Hodgkin lymphoma (HL) by developing a focused translational research program evaluating novel therapies such as radiolabeled monoclonal antibodies, idiotype vaccine therapies, pathway directed agents, and stem cell transplantation. Dr. Vose has been recognized for her NHL research on a national and international level through research awards and invited lectureships worldwide. She is currently the Co-Chair for the National Cancer Institute Lymphoma Sub-Committee and a member of the FDA Oncologic Drug Advisory Committee.

The ideas and viewpoints expressed in this editorial are those of the author and do not necessarily represent any policy, position, or program of NCCN. 
will become an important aspect of lymphoma care in the near future. The NCCN Guidelines will continue to reflect the important changes in clinical care and research regarding lymphoma therapies.

\begin{tabular}{|c|c|c|}
\hline Year & Modifications & New Guidelines Added \\
\hline 2002 & $\begin{array}{l}\text { Fludarabine, cyclophosphamide, } \\
\text { rituximab (FCR) added for CLL }\end{array}$ & HIV-related NHL \\
\hline 2003 & $\begin{array}{l}\mathrm{Ki}-67 \text { added to the mantle cell } \\
\text { lymphoma prognostic index }\end{array}$ & None \\
\hline 2004 & $\begin{array}{l}\text { Groupe d'Etudes des Lymphomes } \\
\text { Folliculaires criteria for follicular } \\
\text { prognosis added }\end{array}$ & $\begin{array}{l}\text { Splenic marginal zone } \\
\text { lymphoma }\end{array}$ \\
\hline 2005 & $\begin{array}{l}\text { Follicular Lymphoma International } \\
\text { Prognostic Index (FLIPI) added }\end{array}$ & None \\
\hline 2006 & $\begin{array}{l}\text { Follicular lymphoma grades } 1-2 \\
\text { separated from follicular lymphoma } \\
3\end{array}$ & $\begin{array}{l}\text { Primary central nervous system } \\
\text { lymphoma }\end{array}$ \\
\hline 2007 & $\begin{array}{l}\text { Revised response criteria using PET } \\
\text { added }\end{array}$ & PTCL \\
\hline 2008 & $\begin{array}{l}\text { CLL with del }(17 p) \text { treatment } \\
\text { recommendations added }\end{array}$ & $\begin{array}{l}\text { Mycosis fungoides/Sézary } \\
\text { syndrome }\end{array}$ \\
\hline 2009 & $\begin{array}{l}\text { Rituximab: hepatitis B reactivation } \\
\text { concern added }\end{array}$ & Primary cutaneous B-cell NHL \\
\hline 2010 & $\begin{array}{l}\text { Bendamustine + rituximab for } \\
\text { first-line treatment of follicular } \\
\text { lymphoma added }\end{array}$ & $\begin{array}{l}\text { Adult T-cell leukemia/ } \\
\text { lymphoma }\end{array}$ \\
\hline \multirow[t]{2}{*}{2011} & \multirow{2}{*}{$\begin{array}{l}\text { Principles of radiation therapy linked } \\
\text { to the guidelines }\end{array}$} & Natural killer/T cell \\
\hline & & $\begin{array}{l}\text { Posttransplant } \\
\text { lymphoproliferative disorder }\end{array}$ \\
\hline \multirow[t]{2}{*}{2012} & \multirow{2}{*}{$\begin{array}{l}\text { Cyclophosphamide, etoposide, } \\
\text { doxorubicin, vincristine, prednisone } \\
\text { (CHOEP) added for PTCL }\end{array}$} & Hairy cell leukemia \\
\hline & & T-cell prolymphocytic leukemia \\
\hline
\end{tabular}

Abbreviations: CLL, chronic lymphocytic leukemia; NHL, non-Hodgkin's lymphoma; PTCL, peripheral T-cell lymphoma. 